\title{
THE ULTRASTRUCTURE OF TASTE BUDS IN THE NEWBORN LAMB
}

\author{
F. TICHÝ \\ Department of Anatomy, Histology and Embryology University of Veterinary Science, 61242 Brno
}

Received June 12, 1991

\begin{abstract}
Tichý F.: The ultrastructure of Taste Buds in the Nerwborn Lamb. Acta vet. Brno, 61, 1992: 83-91.

The ultrastructure of taste buds on circumvallate papillae collected from the tongues of three lambs on the day of birth was studied. Of special concern were the composition of the bud from dark, light and receptor cells, formation of the taste pore and the presence and nature of contacts of intragemmal nerve endings with each of the three cell types.

The taste bud of a lamb at birth involved all three cell types. In comparison with the ultrastructure of buds in adult animals, the neonatal taste buds lacked microvilli at the apical parts of the cells composing the taste pore and only occasionally showed vesicles with dark content in the cytoplasm of receptor cells. The cells of all three types were in contact with the gustatory nerve but the character of the junction was different in the dark cells as compared with the light and the receptor cells.
\end{abstract}

Taste bud, taste pore, gustatory nerve, ultrastructure

Many of the studies concerning the structure of lingual mucosa have reported in detail on the ultrastructure of the taste bud in a variety of animal species as well as in man. The most frequent subjects of study were rabbits (Murray and Murray 1967; Murray et al. 1969; Fujimoto and Murray 1970 and others), rats (Farbman 1965a, b; Murray et al. 1972; Takeda and Hoshino 1975), mice (Takeda 1976), amphibians (Farbman and Yonkers 1971) and man (Takeda 1972; Paran et al. 1975). A comparison of the results reveals a broad range of views on the structure of the taste bud and on the function of cell types involved.

Some authors have been interested in the process of taste bud formation in the epithelium (Beidler and Smallman 1965; Conger and Wells 1969; Farbman 1969, 1980; Fujimoto and Murray 1970; Takeda 1972, 1976) and in the mechanism of taste perception (Adatia and Gehring 1971; Beidler and Gross 1971; Murray 1973; Paran and Mattern 1975; Beauchamp and Cowart 1986; Schiffman 1986).

The data on the ultrastructure of taste buds have shown differences in relation to the species studied or to the taste bud localization (Beidler 1969, 1970; Murray 1969, 1971, 1973; Mattern and Paran 1974; Takeda and Hoshino 1975). First, two basic cell types, termed dark and light cells, were described by Farbman (1965a, b) and Murray and Murray (1967), later Murray et al. (1969) found another type of cells which they called the receptor cell. The exact role for each of the three types has not been defined yet but evidence suggests that it is similar in all taste buds so far studied: the dark cells have supportive and secretory functions, the light cells mediate taste stimuli to the receptor cells which receive the stimulus (Murray 1973; Miatter n and Paran 1974; Paran and Mattern 1975; Takeda 1977).

Processes associated with replacement of used cells in the taste bud are still poorly understood. The original idea that bud cells arise by continuous development of so-called perigemmal cells (Beidler and Smallman 1965; Farbman 1965b) was later considered dubious by some authors (Takeda 1977; Farbman 1980) particularly with respect to the receptor cells. These cells contain certain specific structure in the cytoplasm which indicate their relation to nervous tissue.

Still incomplete is the information concerning the development of taste buds in the lingual epithelium. The initiation of a taste bud is supposed to occur after contact of a nerve fibre with 
epithelial cells (Beidler and Smallman 1965; Farbman 1965b, 1969, 1980; Conger and Wells 1969; Zalewski 1969, 1970, 1972; Fujimoto and Murray 1970; Takeda 1972, 1976). Interesting observations made earlier in the tongues of ovine and porcine foetuses have enabled us to relate the appearance of taste buds in the lingual epithelium to exact periods of foetal development (Tichý and Černý 1989; Tichý 1991a, b, c, d; Tichý 1992). The results presented here give further details on the structure of taste buds in sheep at birth and thus contribute to the understanding of the taste organ in this domestic species.

\section{Materials and Methods}

Samples of circumvallate papillae were collected from the tongues of three lambs on the day of birth. The tissue was immediately fixed with glutaraldehyde in $0.1 \mathrm{M}$ phosphate buffer (300 mmol/l) for $4 \mathrm{~h}$, washed with 4 changes of $0.1 \mathrm{M}$ phosphate buffer and postfixed with $\mathrm{OsO}_{4}$ in $0.1 \mathrm{M}$ phosphate buffer $(40 \mathrm{mml} / \mathrm{l})$ for $1 \mathrm{~h}$. After dehydration with a graded acetone series $(25 \%$, $50 \%, 75 \%, 90 \%, 100 \%$ ) the samples were embedded in Durcupan ACM and polymerized at $60{ }^{\circ} \mathrm{C}$ for 3 days. Fixation, dehydration and embedding were performed at room temperature.

Ultrathin section were made with an Ultracut Reichert-Jung ultramicrotome. They were stained on grids (MESH 100) with uranyl acetate and lead citrate and examined and photographed with a Tesla BS 500 electron microscope.

Semithin sections, $1 \mu \mathrm{m}$ thick, were stained with methylene blue and Azure II (mixed $1: 1$ ) on a plate $50^{\circ} \mathrm{C}$ warm for $1 \mathrm{~min}$.

\section{Results}

Taste buds in the epithelium of circumvallate papillae collected from lambs on the day of birth showed the usual shape, size and localization. By electron microscopy it was possible to distinguish three types of cells: dark cells (Type I), light cells (Type II) and receptor (taste) cells (Type III). The cells of all three types were spindle-shaped and extended from the basement membrane to the taste pore. Below the pore, the cells were joined by extensive connecting complexes consisting of tight junctions and numerous desmosomes (Plates I., II., Figs 1, 2). Frequent bundles of nerve fibres passing through the basement membrane ran in some buds so high that they could be observed near the taste pore (Fig. 1). The cells of all three types were in contact with these nerve fibres.

Dark cells (Type I cells) were slimmer than the other cells, their cytoplasm was darker and their nuclei had a higher content of chromatin. The nucleus was elliptic or spindle-shaped with clusters of heterochromatin usually found near the inner surface of the nuclear envelope (Plate III., Fig. 3).

The cytoplasm was rich in the granular endoplasmic reticulum accumulated in the supranuclear area and the basal part of the cell. The apical part of the cell contained numerous bundles of filaments varying in thickness. Towards the taste pore the cell elongated forming a thin protrusion which ran through the pore up above the level of the surrounding epithelium; its terminal part was differentiated into irregular elevations. The cytoplasm in the protrusion was filled with parallel bunches of fine filaments (Fig. 1). Below the apex, the cytoplasm contained clusters of dark granules; these were oval in shape and their size varied from $100 \mathrm{~nm}$ to $200 \mathrm{~nm}$ (Fig. 1). The granules were enveloped in membranes and contained dark homogeneous material similar to the substance found in the dark areas of the pore (Figs 1,2). The Golgi apparatus, usually well developed, was situated above the nucleus. Some of its cisternae contained dense substance resembling the content of dark granules in the apical cytoplasm. The supra- 
nuclear region frequently included vacuoles varying in size. In both the apical and the basal parts of the cytoplasm, numerous elongated mitochondria with conspicuous cristae were present (Fig. 3).

Nerve fibres were frequently seen. They penetrated deep into the cytoplasm and, particularly in the basal part of the cell, their contact with the cells imitated Schwann's sheath. However, structures indicating synaptic junction were not observed (Fig. 4).

Light cells (Type II cells) were considerably larger than Type I celis and were mostly found in the central part of the taste bud. Their light cytoplasm had low density, round nuclei were large with diffuse chromatin. Occasionally, karyolemma was folded into shallow invaginations. One or two nucleoli of reticular type were a frequent finding (Plates IV., V., Figs 4, 5).

The cytoplasm, especialy in the region above the nucleus, contained numerous vesicles varying in size from $60 \mathrm{~nm}$ to $200 \mathrm{~nm}$ and was rich in smooth endoplasmic reticulum (Fig 3, Plate VI., Fig. 6). Some of the large vesicles were filled with finely granulated material. The Golgi apparatus was found in the perinuclear region and was more extensive than in Type I cells. Few lysosomes were seen in the peripheral cytoplasm. Mitochondria, smaller than in Type I cells, were oval or elliptic, usually situated above the nucleus. The cytoplasm, mainly its apical part, involved numerous glycogen inclusions (Fig. 3). On rare occasions lamellae anulatae were seen near the nucleus (Fig. 4).

Similarly to Type I cells, towards the pore the cell formed a protrusion which entered the pore with its terminal part. However, unlike the dark cells, this part, though reaching above the epithelial surface, was not differentiated into elevations. The cytoplasm of this region involved small light vesicles and fine bundles of parallel filaments which, in some instances, extended into the cytoplasmic areas below the pore (Fig. 1).

The connection of light cells with nerve fibres was slightly different from that observed in the dark cells. Although the contact was close and extensive, the light cells and nerve fibres never formed a "mesaxon" or any specialized structure like synaptic junction (Fig. 6, Plate VII., Fig. 7).

Receptor cells (Type II cells) were similar to the light cells in shape and cytoplasm density (Plate VIII., Fig. 8). They were situated in the central region of the bud among the light cells. Their basal parts did not extend as far as the basement membrane. Connection by means of desmosomes was observed with both the light and the dark cells.

The nucleus was an intermediate type between the elongated nucleus of the dark cell and the round one of the light cell. As a rule, the karyolemma was folded into deep, sometimes branched invaginations (Fig. 7). The amount of chromatin in the karyoplasm was higher than that in Type II cells.

The cytoplasm contained well formed extensive endoplasmic reticulum and free ribosomes. Mitochondria had a typical rounded shape and distinct cristae mitochondriales. The most of them were found close to the nucleus (Figs 6,8). This area also showed fine bundles of filaments. The Golgi apparatus in the perinuclear region was rather small (Fig. 8). Below and above the nucleus the cytoplasm contained numerous small vesicles $(30 \mathrm{~nm}-60 \mathrm{~nm})$ with light content. Larger $(100 \mathrm{~nm}-150 \mathrm{~nm}$ ) vesicles with dark content were not so frequent (Fig. 8). Although the amounts of both vesicle types increased in areas of cell-to-nerve fibre contact, no increase in cell membrane density was observed.

The apical part of the cell extended towards the pore, with its cytoplasm con- 
taining infrequent bundles of fine filaments and high numbers of vesicles displaying a great variety of sizes and shapes.

The numerous nerve fibres in the lamina propria mucosae were surrounded only with the cytoplasm of Schwann's cells. These fibres showed high amounts of neurotubules, vesicles, mitochondria and large dense bodies. It was not possible to distinguish the central basal part of the taste bud from the mucosal connective tissue lying below because the area was filled with cytoplasmic protrusions of Schwann's cells, nerve fibres, dark cells and even some light cells. The nerve fibres situated within the bud were of two types. The more numerous and thinner ones contained only neurotubules, occasional mitochondria and a few filaments. The thicker fibres contained many mitochondria and $40-60 \mathrm{~nm}$ vesicles. The dark cells were frequently found around the thinner nerve fibres while the light and receptor cells were in contact with the thicker fibres.

\section{Discussion}

Although some differences have been described in the ultrastructure of taste buds in relation to their location in the lingual epithelium and the species studied (Farbman 1965b; Beidler 1969, 1970; Murray 1969, 1971, 1973; Mattern and Paran 1974; Takeda and Hoshino 1975) the principal structure of the taste bud is always the same, consisting of three types of cells: dark, light and receptor ones.

In the lamb at birth these three types of cells were found in the taste buds on the circumvallate papillae and their ultrastructure and the range of organelles corresponded to the data reported for some laboratory animals (Fujimoto and Murray 1970; Takeda and Hoshino 1975). The dark cells are throught to have supportive function because of the presence of filaments in the cytoplasm, but some secretory activity has also been described (Murray 1973; Mattern and Paran 1974; Paran and Mattern 1975; Takeda 1977). The high amounts of secretory granules in the supranuclear region which were filled with dark homogeneous substance indicated that this might be the source of pore substance present in the porus gustatorius. The confirmation was provided by Takeda and Hoshino (1975) who found some granule exocytosis in the dark cells and by the results of biochemical tests (Takeda 1977; Farbman 1980). Our observations showed granules with dark content being present in the apical cytoplasm of Type I cells. Their average size corresponded with that found earlier in other mammalian species (Takeda and Hoshino 1975) but their occurrence was less frequent. It remains to be answered if this lower amount of dark granules in Type I cells is characteristic for the ovine specits, is related to the age at which the animal was examined or depends on the location of the taste bud in epithelium of the circumvallate papilla. The results of ultrastructural studies of taste buds in various mammals (Murray et al. 1972; Takeda 1972, 1976; Parant and Mattern 1975; Paran et al. 1975) have generally shown high amounts of these granules in dark cells; some observed variation in amounts have been explained by different positions of the buds on the papilla (Murray 1973; Paran and Mattern 1975; Takeda and Hoshino 1975). In our view the granules of dark cells are formed in the period when taste buds begin functioning, i. e. immediately after birth. This assumption is supported by our findings of dark substance in the Golgi apparatus cisternae of Type I cells and by conclusions of some 
authors concerning the role of the pore substance in the process of taste perception (Jahnke 1972; Murray 1973; Nada and Hirata 1975; Beauchamp and Cowart 1986; Schiffman 1986).

A marked difference from the common description of taste bud ultrastructure was the absence of long, slim microvilli in the apical part of Type I cells. It was found that the apex terminated with a thin protrusion differentiated into irregular elevations which extended through the porus gustatorius above the level of the surrounding epithelium. It can be expected that with postnatal development the terminal part of the cell passing through the pore will further differentiate giving rise to typical microvilli. If it is true that the cell population of the taste bud including the dark cells is subjected to continual and permanent exchange (Beidler and Smallman 1965; Adatia and Gehring 1971; Farbman 1980) induced by contact of the cells with nerve fibres (Baratz and Farbman 1975; Takeda 1976), then in can be concluded that the development of microvilli through differentiation of the terminal parts will repeat itself at certain intervals. Becarse such a process has not been described in the literature it is suggested that the absence of microvilli in the apical parts of Type I cells in taste buds of the lamb is specific for this species.

The close contact between dark cells and nerve fibres made some authors believe that these were receptor cells, $i$. e. the taste cells (Farbman 1965a). Nerve fibres before entering the basal part of the taste bud were enveloped only in Schwann's sheath; this no longer existed in the bud but the fibres were sunk deep into the cytoplasm of the dark cells. The contact, however, bore no resemblance to synaptic junction. In this our results agree with earlier findings of $\mathrm{Pa}$ ran et al. (1975). It is assumed that the dark cells function as supporting as well as secretory cells and may also have a role in substituting peripheral neuroglia; most probably, they are also involved in transport of taste stimuli.

In contrast to the dark cells, the light cells of the taste bud in the lamb did not show any signs of secretory activity. It is open to speculation whether this cells type evolves in the course of continuous differentiation from the dark cells (Murray et al. 1969) or is a stage in the evolution of an independent cell population (Farbman 1980). We share the view on gradual cell differentiation enabling the bud to fulfill a variety of functions. The presence of numerous vesicles and vacuoles in the cytoplasm, the absence of the granular endoplasmic reticulum and the regular occurrence of nucleoli of reticular type indicate that the light cells exert only average metabolic activity.

It was rather suprising to find that the apical parts of the light cells, which like in the dark cells passed through the taste bud up above the surrounding epithelium, were not differentiated into microvilli; as reported in other mammalian species (Farbman 1965a; Murray et al. 1969; Paran et al. 1975; Takeda 1977). The irregular elevations seen in the dark cells were also missing. Whether this is a species-specific characteristic or still incomplete differentiation of this part of the $\mathrm{cl} 1 \mathrm{l}$; is difficult to decide.

The high rumber of vesicles in the apical cytoplasm of Type II cells indicates involvement in taste perception (Farbman and Yonkers 1971; Schiffman 1986) for which the close and often extensive contacts of the cells with nerve fibres may also be important. Murray and Murray (1967) make a distinction between nerve fibres (thinner structures) and nerve endings (larger structures). The contact of light cells with nerve endings is obvious but its function is not clear because the true synapse has not been observed. Although some authors 
(Murray and Murray 1970; Paran et al. 1975) point at the role of small, perhaps synaptic, vesicles in the axoplasm of nerve endings, we favour the opinion of Farbman and Yonkers (1971) that these cells function as mediators between the stimulus and the receptor. On the other hand, the process of continual exchange of taste bud cells through development of one type into another suggested by Farbman (1980) is also worth consideration. The light cells here could be the last stage in an evolutionary series, i. e. the stage following the receptor cell, and our finding of the lamellae anulatae could be taken as a proof of cytoplasm differentiation. However, no similar findings have been reported in the literature. As can be seen, the range of views is broad and explanations are often conflicting. Murray and Murray (1970) compare these non-specific contacts between nerve endings and Type II cells to efferent endings observed in other types of sensory epithelia. We cannot discuss these facts because our study was not performed at this level. Nevertheless, the presence of branching nerve fibres observed in the taste bud together with the findings of synaptic junctions described by Murray and Murray (1970) and Takeda (1977) allow us to draw a conclusion that conditions for functional connection of all cell types may exist. It remains to be decided if the nerve fibres associated with Type II cells make a system identical with or different from that of fibres supplying the receptor cells.

The receptor cells were similar both in appearance and localization to the light cells but for one conspicuous feature, which was the presence of karyolemma folded into deep invaginations. This is thought to be a species-specific phenomenon because the type of nuclear envelope is not mentioned in the literature.

The apical part of the receptor cells is almost jdentical with that of the light cell, which makes their differentiation within the taste bud very dificult ( $P$ aran et al. 1975).

The current opinion that Type III cells function as taste receptor is based particularly on the presence of minute vesicles with light content and larger vesicles with dark content. In the cytoplasm these vesicles are accumulated in the area of contanct between the cell and the nerve endings. However, in newborn lambs the dark vesicles were present in the receptor cells only on rare occasions, which was a situation different from the vesicle aggregates described by Takeda (1977) and others. Nevertheless it can be assumed that the number of dark vesicles will increase with the developing function of the taste bud in growing animals. It has been reported that the vesicles contain substances similar in composition to monoamines known to act as neurotransmitters of stimuli from the receptor cells to the gustatory nerve (De Han and Graziadei 1973; Takeda 1977; Shepherd et al. 1986). From this some authors conclude that the receptor cells are derived from the nerve tissue (Takeda 1977; Farbman 1980).

Type III cells were found in frequent contact with nerve endings in a manner similar to that seen in the light cells, with the exception that their cytoplasm in the area of contact contained minute vesicles. These have earlier been described as synaptic vesicles (Paran et al. 1975). The presence of a typical pre-synaptic dense layer along the cell membrane was not seen in the ovine lingual tissues examined; this may be due to the fact that this structure occurs only occasionalle. The structure has been reported by some authors (Murray and Murray 1970; Murray 1973) while others write about the absence of membrane differentiation in the area of synaptic contact between taste cells and nerve endings (Paran et al. 1975). The structure of synapse may be different in various animal species or may not be discernible at carly stages of their development. 
Our observations show that the cell structure of the taste bud in a newborn lamb is in general agreement with the ultrastructural picture as has been presented for different mammalian species. Some differences found here could be explained by the specific characteristics of the ovine species or, which is more likely, by examination at a stage when differentiation was still incomplete. It cannot therefore be concluded if the taste bud of a newborn lamb is functioning fully or not.

\section{Ultrastruktura chutových pohárků u ovce po narození}

$\mathrm{Na}$ hrazených papilách, odebraných $\mathrm{z}$ jazyků tř́ jehňat $\mathrm{v}$ den narození, byla sledována ultrastruktura chutových pohárků. Pozornost byla zaměřena na zjištění přítomnosti tmavých, světlých a receptorových buněk v pohárcích těsně po narození, dále na utváŕení oblasti chutového póru a na přítomnost, popřípadě charakter kontaktu intragemálně uložených nervových vláken $s$ jednotlivými typy buněk.

Bylo zjištěno, že $\mathrm{v}$ chutových pohárcích jehněte jsou při narození prítomny všechny tři buněčné typy. Odlišnosti oproti popisům ultrastruktury pohárků dospělých jedinců jiných druhů savců spočívají zejména $\mathrm{v}$ absenci mikroklků na apikálních částech jednotlivých buněk $\mathrm{v}$ oblasti chutového póru a $\mathrm{v}$ pouze ojedinělém výskytu vesikul $\mathrm{s}$ tmavým obsahem $\mathrm{v}$ cytoplasmě receptorových buněk. Dále bylo zjišstěno, že všechny buňky jsou v kontaktu s nervovými vlákny, avšak strukturální usporáádání těchto kontaktů je u buněk tmavých odlišné od buněk světlých a receptorových.

\section{Ультраструктүра вкүсовых почек овец после рождения}

На желобоватых сосочках, полученных на языках трех ягнят в день их рождения, проводили исследования ультраструктуры вкусовых почек. Внимание направили на выявление темных, светлых и рецепторных клеток в почках непосредственно после рождения, на образование области вкусового отверстия и на наличие или характер контакта интрагемально расположенных нервных волокон с отдельными типами клеток.

Было установлено, что во вкусовых почках ягнят при рождении присутствуют все три типа клеток. Различие по сравнению с описанием ультраструктуры почек взрослых особей других видов. млекопитающих заключается, в особенности, в отсутствии микроворсинок на верхүшечной части отдельных клеток в области вкусового отверстия и только в единичных случаях стречающемся наличии пузырьков с темным содержанием в цитоплазме рецепторных клеток. Было также установлено, что все клетки находятся в контакте с нервными волокнами, однако структурное расположение данных контактов по сравнению со светлыми и рецепторными клетками у темных клеток отличается.

\section{References}

ADATIA, A. K.-GEHRING, E. N.: Proprioreceptive innervation of the tongue. J. Anat,, 110, 1971: $215-220$ 
BARATZ, R. S.-FARBMAN, A. I.: Morphogenesis of rat lingual filiform papillae. Am. J. Anat., 143, 1975: 283-302

BEAUCHAMP, G. K.-COWART, B. J.: Development of Sweet Taste Sweetness. Ilsi human nutrition Reviews, Symp. on Sweetness, Geneva, Switzerland, May 21-23, 1986: 127-130

BEIDLER, J. M.: Innervation of rat fungiform papilla. In: Olfaction and taste 3, Pfaffman ed. New York: Rockefeller Univ. Press, 1969: 352-369.

BEIDLER, J. M.: Physiological properties of mammalian taste receptors. In: Taste and smell in vertebrates. Wolstenholme and Knight, eds. Ciba Found. Symp. London, J. Q A. Churchill, 1970: $51-67$

BEIDLER, J. M.-GROSS, G. W.: The nature of taste receptors sites. In: Contribution to sensory physiology 5, Neff, ed. New York: Academie Press, 1971: 97-127

BEIDLER, J. M. - SMALLMAN, R. L.: Renewal of cells within taste buds. J. Cell. Biol., 27, 1965: 263-272

CONGER, A. D.-WELLS, M. A.: Radiation and aging effect on taste structuer and function. Radiat. Res:, 37, 1969: 31-49

DE HAN, R.-GRAZIADEI, P. P. C.: The innervation of frog's taste organ. "A histochemical study". Life Sci., 13, 1973: $1435-1449$

FARBMAN, A. I.: Fine structure of the taste bud. J. Ultrastruct. Res., 12, 1965a: 328-350

FARBMAN, A. I.: Electron microscope study of the developing taste bud in rat fungiform papilla. Devel. Biol., 11, 1965b: 110-135

FARBMAN, A. I.: Fine structure of degenerating taste buds after denervation. J. Embryol. Exp. Morph., 22, 1969: 55-67

FARBMAN, A. I.: Renewal of taste - bud cells in rat circumvallate papillae. Cell Tissue Kinet., 13, 1980: $349-357$

FARBMAN, A. I. - YONKERS, J. D.: Fine structure of the taste bud in the mud puppy, Necturus maculosus. Amer. J. Anat., 131, 1971: 353-370

FUJIMOTO, S.-MURRAY, R. G.: Fine structure of degeneration and regeneration in denervated rabbit vallate taste buds. Anat. Rec., 168, 1970: 393-414

JAHNKE, K.: Der feinstrukturelle Nachweis der Acetylcholines-teraseAktivität in den Geschmacksknospen der Papillae foliatae des Kaninchens. Arch. Klin. exp. Ohr., Nas., u. Kehlkopf-Heilk., 203, 1972: 125-152

MATTERN, C. F. T.-PARAN, N.: Evidence of a contractile mechanism in the taste bud of the mouse fungiform papilla. Exp. Neurol., 44, 1974: 461-469

MURRAY, R. G.: Cell tapes in rabbit taste buds. In: Olfaction and taste III, Pfaffman, ed. New York, Rockfeller Univ. Press, 1969: 331-344

MURRAY, R. G.: Ultrastructure of taste receptors. In: Handbook of sensory physiology, vol. IV Chemical senses, part 2 Taste, Beidler, ed. Berlin-Heidelberg-New York: Springer, 1971: $31-50$

MURRAY, R. G.: The structure of taste buds. In: Ultrastructure of sensory organ, vol. 1, Friedman, ed. Amsterdam: North Holland, 1973: 1-81

MURRAY, R. G. - MURRAY, A.: Fine structure of taste buds of rabbit foliate papillae. J. Ultrastr. Res., 19, 1967: 327-353

MURRAY, R. G.-MURRAY, A.: The anatomy and ultrastructure of taste endings. In: (ed. by) G. E. W. Wolstenholme and J. Knight: Taste and smell in vertebrates. London, J. and A. Churchill, 1970: 3-30

MURRAY, R. G.-MURRAY, A. - FUJIMOTO, S.: Fine structure of gustatory cells in rabbit taste buds. J. Ultrastr. Res., 27, 1969: 444-461

MURRAY, R. G.-MURRAY, A.-HELLEKANT, G.: Fine structure of taste buds of rat fungiform papillae. In: Proceedings of the Fourth International Symposium on Olfaction and Taste. Schneider, ed. Stuttgart: Wissenschaftliche Verlagsgesellschaft MBH 1972

NADA, O.-HIRATA, K.: The occurrence of the cell type containing a specific monoamine in the taste bud of the rabbit's foliate papilla. Histochemistry, 43, 1975: 237-240

PARAN, N.-MATTERN, C. F. T.: The distribution of acetylcholinesterase in buds of the rat vallate papilla as determined by electron microscope histochemistry. J. comp. Neurol., 159, 1975: 29-44

PARAN, N.- MATTERN, C. F. T.-HENKIN, R. I.: Ultrastructure of the taste bud of the human fungiform papilla. Cell. Tiss. Res., 161, 1975: 1-10

SCHIFFMAN, S. S.: Recent insights into the mechanism of taste transduction and modulation. Food Chemistry E 3648, 21, No 4, Else rier Applied Sci., 1986: 259-263

SHEPHERD, G. M.-GETCHELL, T. V.-MISTRETTA, CH. M.: Questions of taste and smell. Nature E 7095, Vol. 324, No 6092, News and Views, 1986: 17-23 
TAKEDA, M.: Fine structure of developing taste buds human fetal circumvallate papillae (in Japanese with English summary). Acta anat. nippon., 47, 1972: 325-337

TAKEDA, M.: An elctron microscopic study on the innervation in the taste buds of the mouse circumvallate papillae. Arch. histol. jap., 39, 1976: 257-269

TAKEDA, M.: Uptake of 5-hydroxytryptophan by gustatory cells in the mouse taste bud. Arch. histol. jap., 40, 1977: 243-250

TAKEDA, M.-HOSHINO, T.: Fine structure of taste buds in the rat. Arch. histol. jap., 37, 1975: $395-413$

TICHÝ, F.: Morfogeneze hrazené papily a diferenciace chutových pohárků u prasete $\mathrm{v}$ ontogenezi. Scripta medica Brno, 64, 1, 1991a: 50

TICHÝ, F.: The morphogenesis of circumvallate papillae and the differentiation of taste buds in the pig at 41 to 64 days of prenatal development. Acta vet. Brno, 60, 1991a: 99-110

TICHÝ, F.: The morphogenesis of circumvallate papillae and the differentiation of taste buds in the porcine foetus ftom day 76 till birth and in the adult pig. Acta vet. Brno, 60, 1991c: $307-315$

TICHÝ, F.: Alkalická fosfatáza a nespecifická esteráza ve sliznici jazyka ovce. Scripta medica Brno, 64, 3, 1991d: 177

TICHYY, F.: The morphogenesis of selected lingual papillae in ovine and porcine foetuuses observed by scanning electron microscopy. Acta vet. Brno, 61, 1992: 3-10

TICHÝ, F.-ČERNÝ, H.: The morphogenesis of circumvallate papillae and diferentiation of taste buds in sheep ontogeny. Acta vet. Brno, 56, 1987: 261-274

ZALEWSKI, A. A.: Role of nerve and epithelium in the regulation of alkaline phosphatase in gustatory papillae. Exp. Neurol., 23, 1969: 18-28

ZALEWSKI, A. A.: Regeneration of taste buds in the lingual epithelium after excision of the vallate papilla. Exp. Neurol., 26, 1970: 621-629

ZALEWSKI, A. A.: Regeneration of taste buds after transplantation of tongue and ganglia grafts to the anterior of the eye. Exp. Neurol., 35, 1972: 519-528 


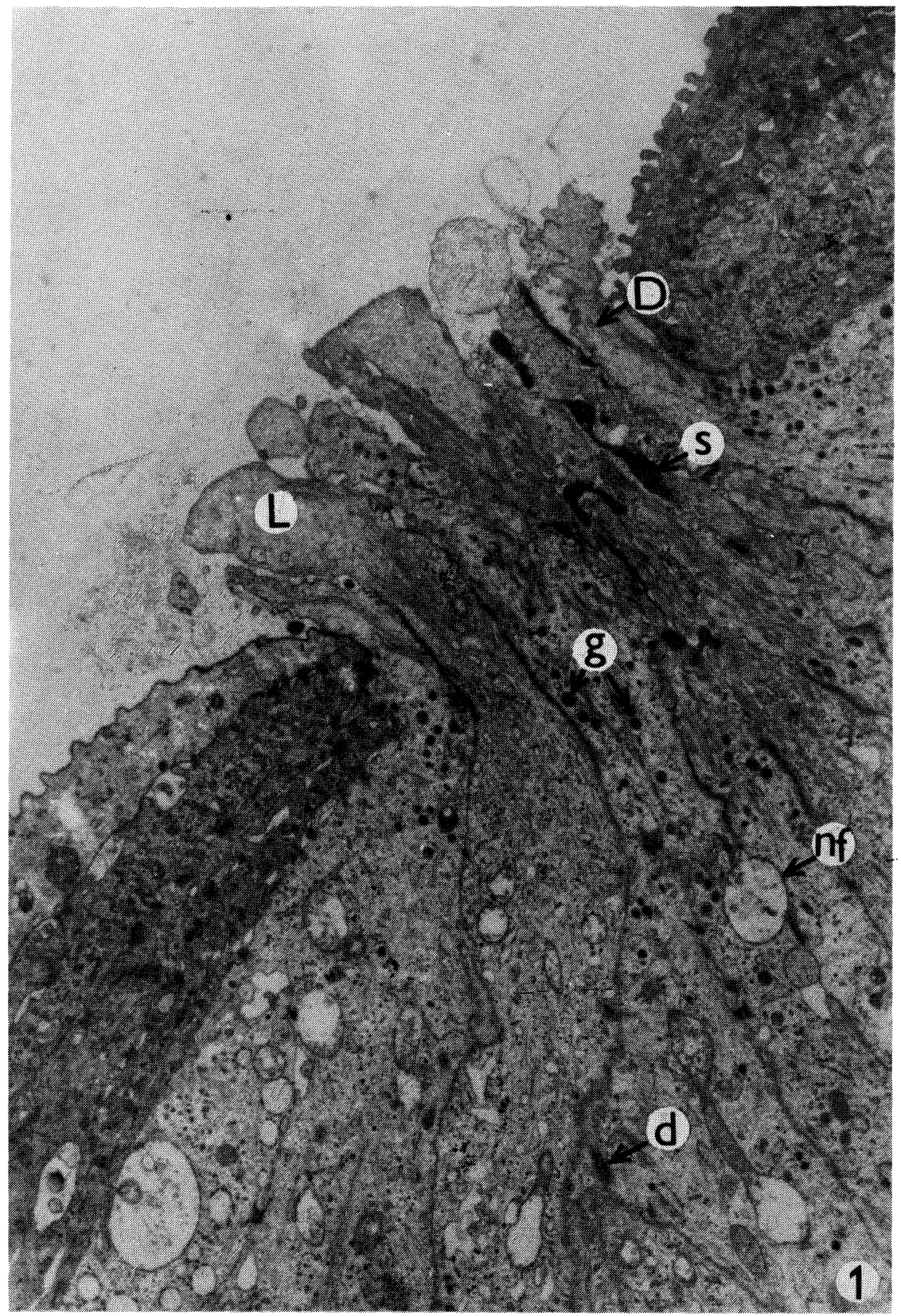

Fig. 1: Taste pore of a bud on the circumvallate papilla in the lamb. Terminal parts of a dark cell (D) and a light cell (L). Regions of dark pore substance (s). Dark secretory granules in the dark cell cytoplasm (g). Desmosomes between the dark and the light cells (d). Nerve fibre (nf). Magnification: $\times 8,000$. 


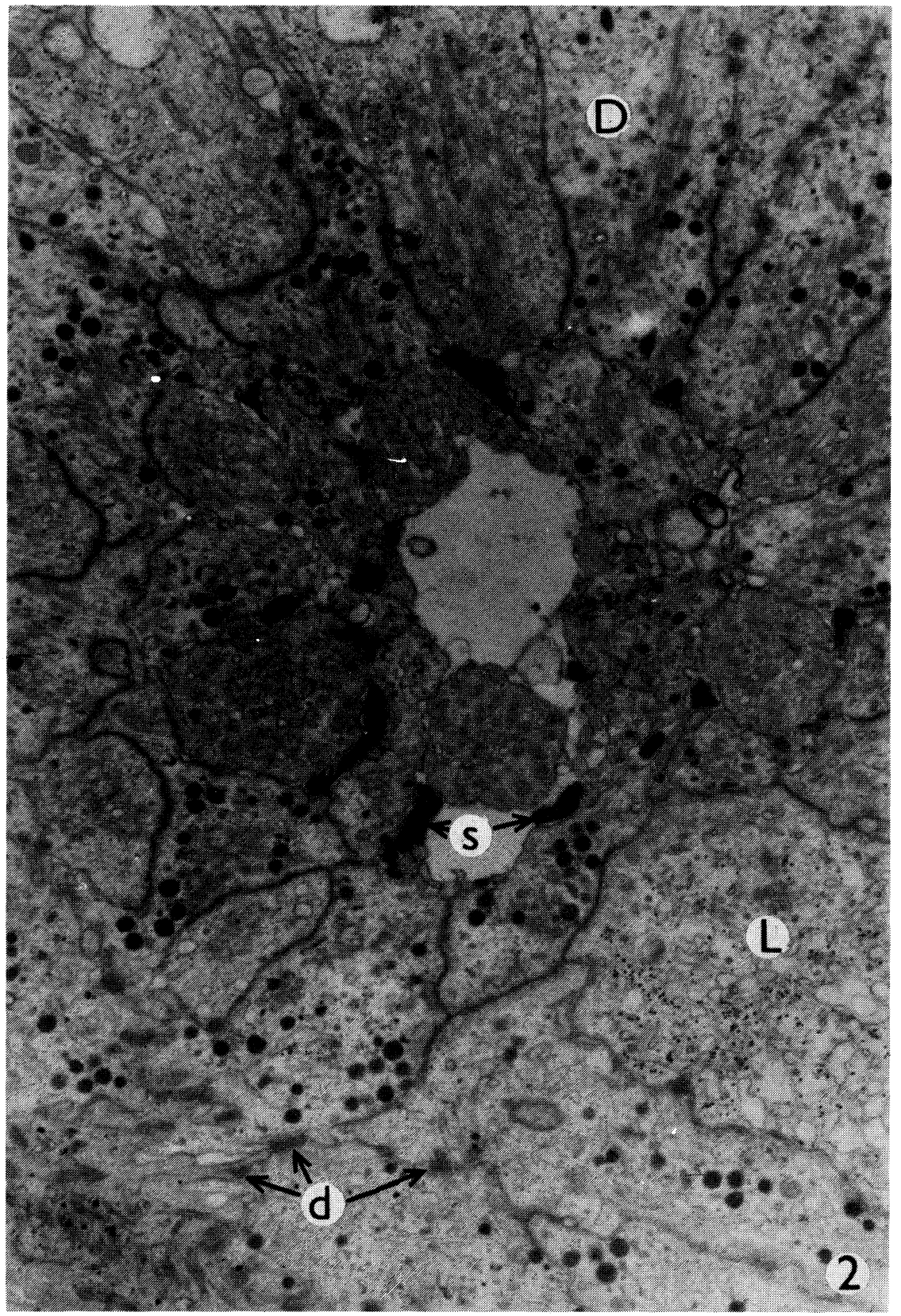

Fig. 2: Cross section trough a taste pore. The apical cytoplasm of a dark cell (D) with bundles of tonofilaments and secretory granules. A light cell (L) with glycogen inclusions and numerous vesicles. Desmosomes between dark cells (d). Dark substance in the pore (s). $\times 12,000$ 


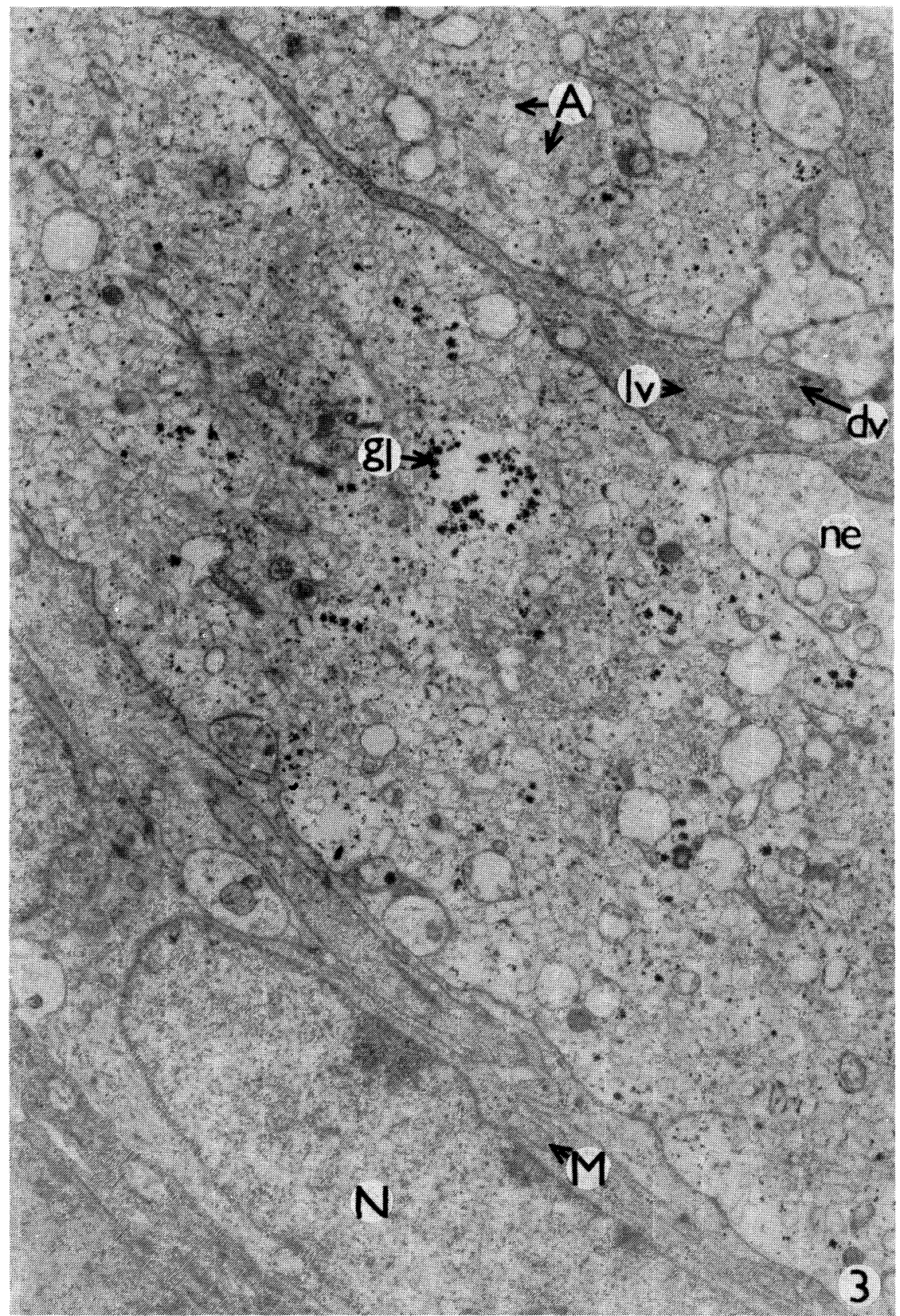

Fig. 3: Peripheral part of the upper half of a taste bud in the lamb. The nucleus $(\mathrm{N})$ in a dark cell, elongated mitochondria (M) in the cytoplasm. Glycogen inclusions (gl) and cisternae of the agranular endoplasmic reticulum (A) in the light cell cytoplasm. Light vesicles (lv) and dark vesicles (dv) in the receptor cell cytoplasm. Nerve endings (ne) between the light cell and the receptor cell. $\times 8,000$. 


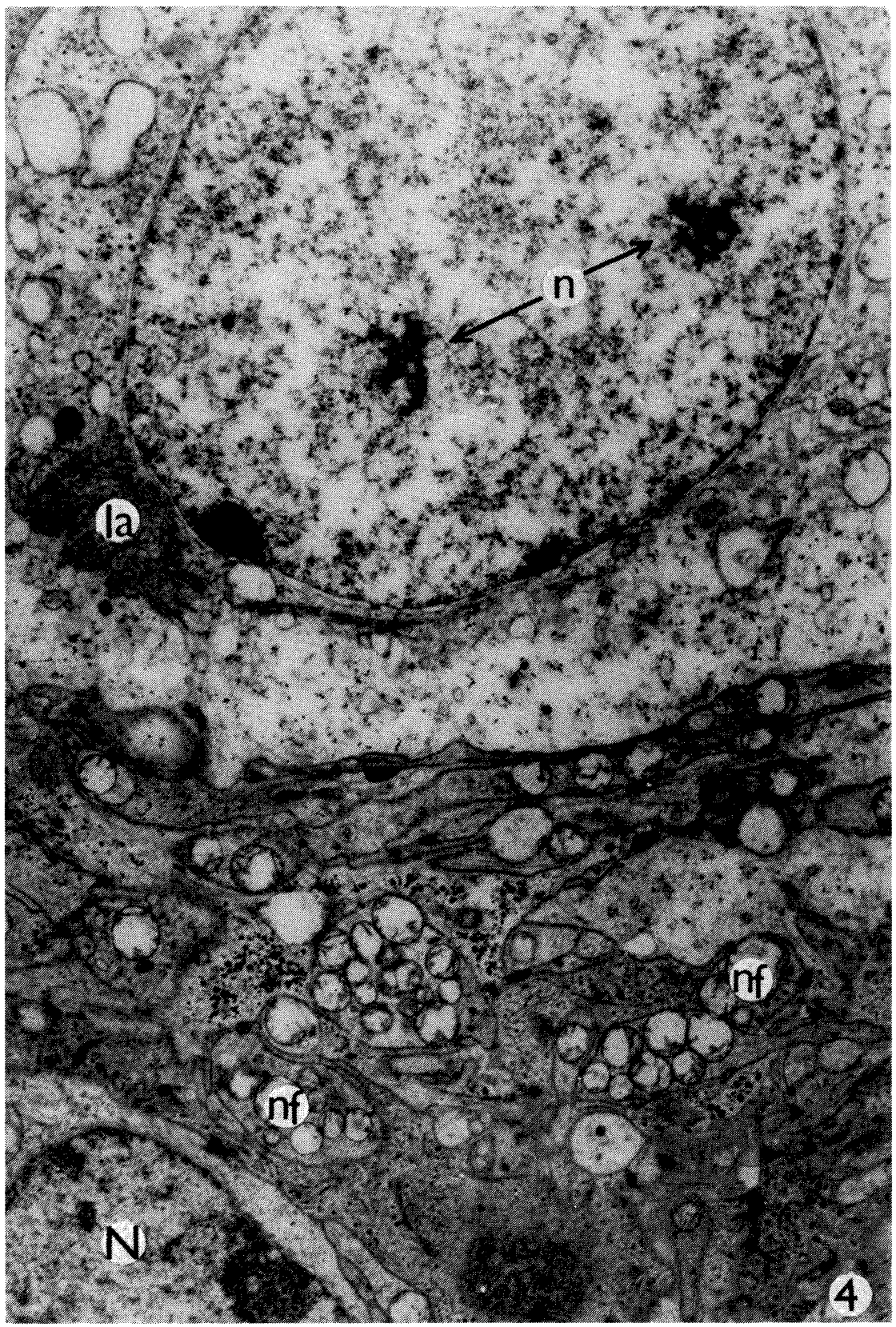

Fig. 4: Basal part of a taste bud in the lamb. The light cell nucleus with reticular type nucleoli (n). Lamellae anulatae (la) The nucleus of a receptor cell (N). Numerous nerve fibres (nf) enclosed in dark cell processes. $\times 12,000$. 


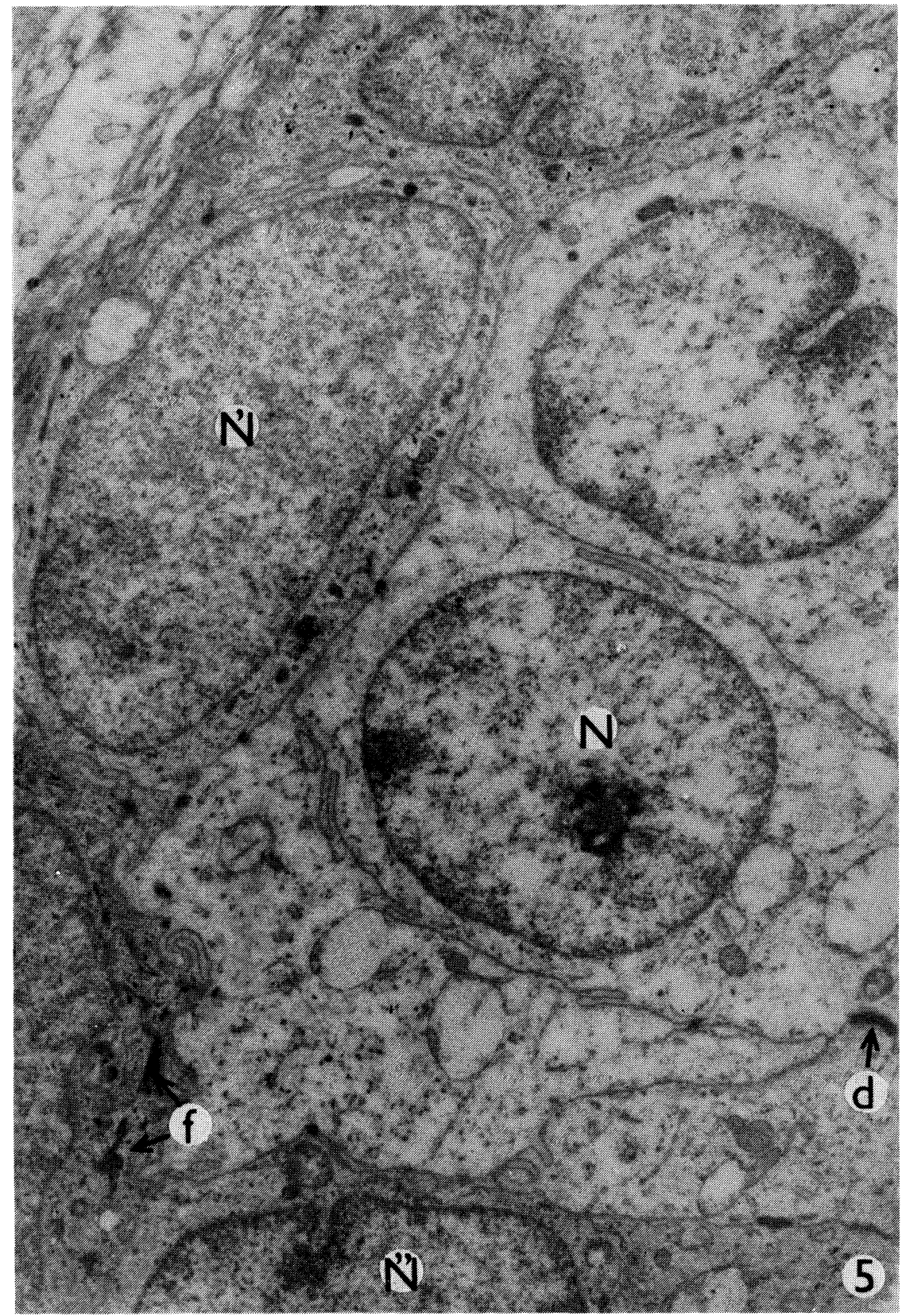

Fig. 5: Peripheral part of the lower half of a taste bud in the lamb. The light cell nucleus (N) with a reticular type nucleolus. Light cells connected with desmosomes (d). Dark cell nucleus (N'), dark cell cytoplasm with bundles of tonofilaments (f). Part of a receptor cell with the nucleus $\left(\mathrm{N}^{\prime \prime}\right) . \times 8,000$. 


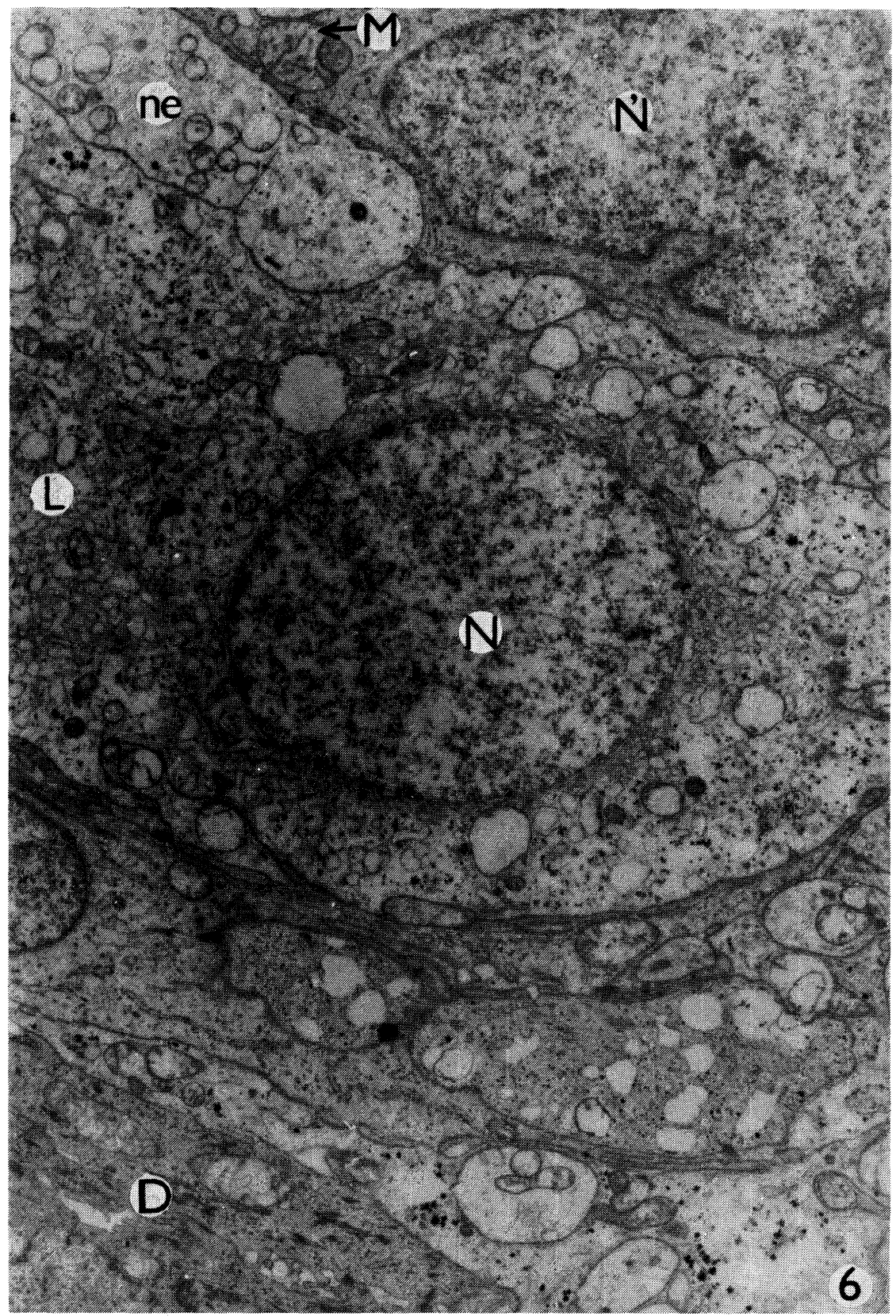

Fig. 6: Central part of a taste bud in the lamb. Light cell nucleus $(\mathrm{N})$, receptor cell nucleus (N'). Light cell cytoplasm (L) with many cisternae of the agranular endoplasmic reticulum. Rounded mitochondria (M) in the dark cell cytoplasm. A nerve ending (ne) between the light and the receptor cell. Part of the dark cell cytoplasm (D) with tonofilaments and mitochondria. $\times 8,000$ 


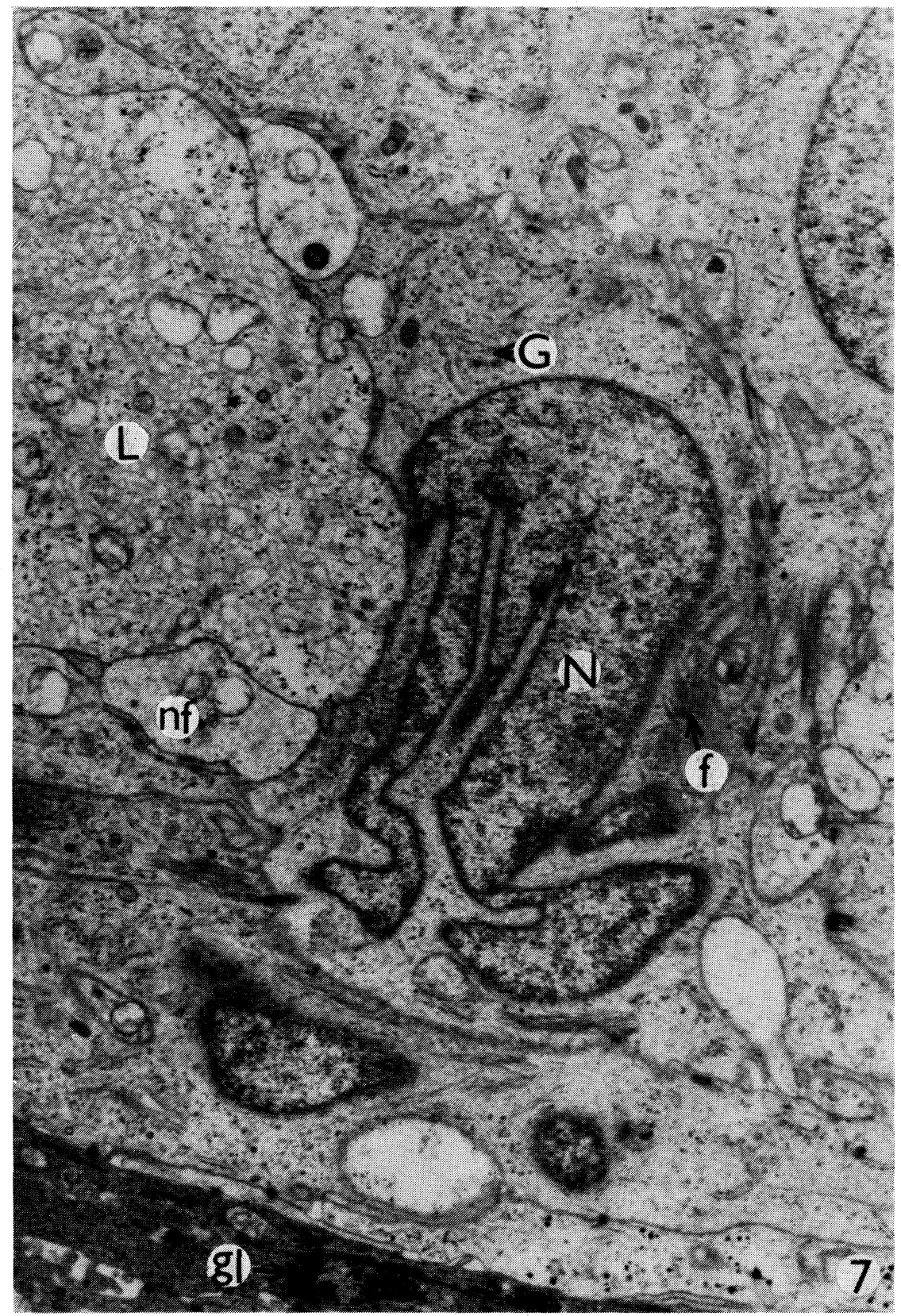

Fig. 7: Peripheral part of a taste bud in the lamb. A receptor cell with the nucleus $(\mathrm{N})$ showing deep, branching invaginations of the karyolemma. The cytoplasm contains fine budles of tonofilaments (f) and a small Golgi apparatus (G). The light cell cytoplasm. (L) with vacuoles and agranular endoplasmic reticulum cisternae. Nerve fibre (nf). Part of a perigemmal cell with glycogen inclusions (gl) in the cytoplasm. $\times 8,000$. 


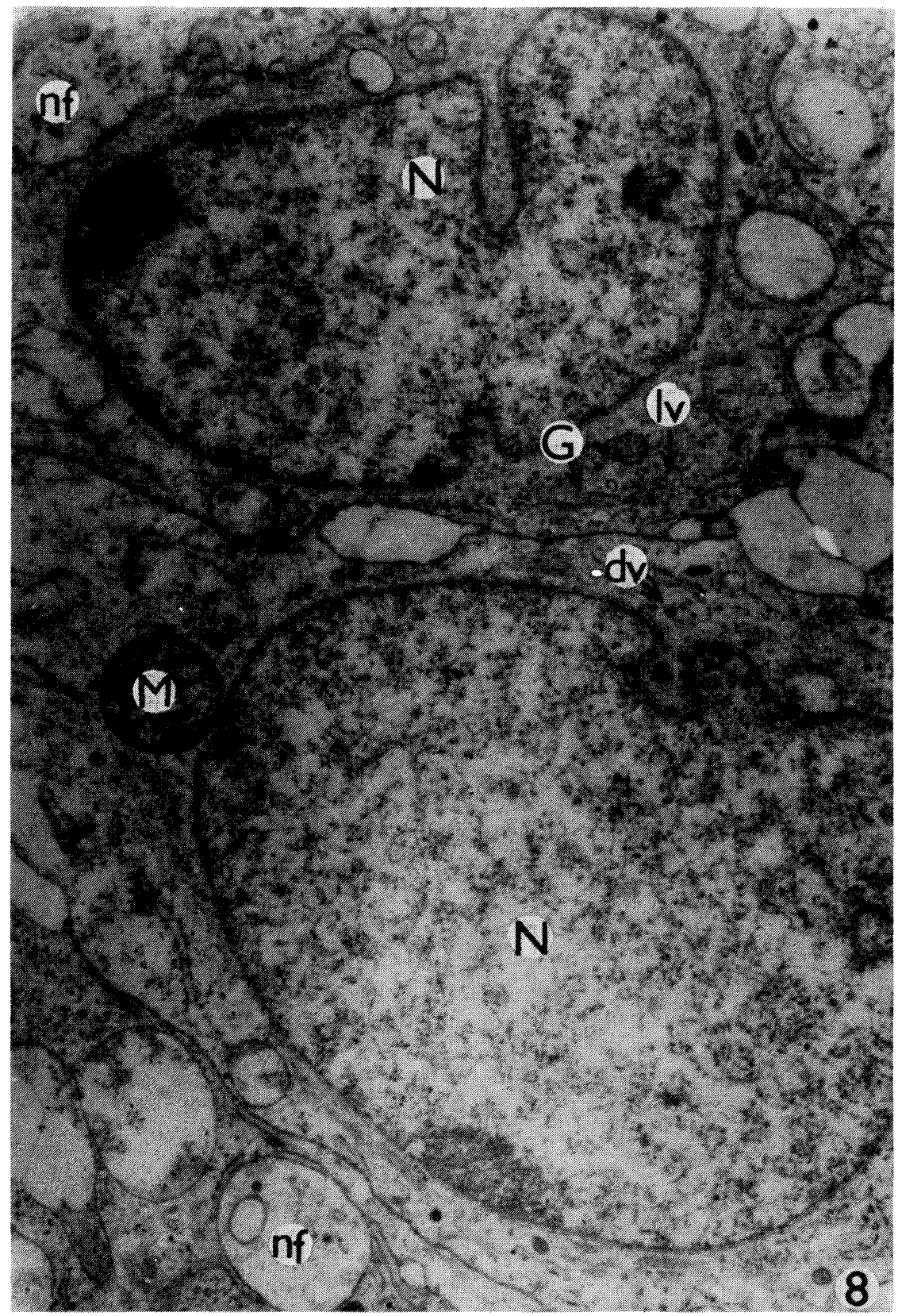

Fig. 8: A pair of receptor cells from the central part of a taste bud with nuclei $(\mathrm{N})$ and rounded mitochondria (M). The cytoplasm includes dark vesicles (dv), small Golgi apparatus (G) and clusters of light vesicles (lv). Nerve fibres (nf) $\times 12,000$. 